\title{
Natężenie ruchu turystycznego w Pienińskim Parku Narodowym
}

Turystykę na obszarach chronionych coraz częściej rozpatruje się w kontekście zjawiska masowego, wielkoprzestrzennego. Ruch turystyczny w parkach narodowych, rezerwatach przyrody, parkach krajobrazowych i innych formach obszarowej ochrony przyrody charakteryzuje się w Polsce dynamicznym rozwojem, podobnie jak towarzyszące mu usługi. Zwiększająca się liczba turystów odwiedzających strefy chronione znajduje odzwierciedlenie w liczebności i strukturze podmiotów gospodarczych w ich otoczeniu. Istotne staje się więc monitorowanie ruchu turystycznego, w tym jego natężenia, zmian przestrzennego rozkładu, sylwetki i preferencji turysty w obrębie obszarów chronionych oraz badanie jego wpływu na funkcjonowanie lokalnej gospodarki. Skłaniają do tego także coraz liczniej pojawiające się w literaturze przykłady niekorzystnych oddziaływań turystyki na środowisko, niejako wymuszające potrzebę monitorowania takich aspektów antropopresji.

Badania ruchu turystycznego w Pienińskim Parku Narodowym, prowadzone przez Studenckie Koło Naukowe Geografów UP w Krakowie w 2007, 2008 i 2009 roku, pozwoliły na określenie poziomu natężenia ruchu turystycznego i jego przestrzennych zmian, w tym wyodrębnienie odcinków szlaków najczęściej uczęszczanych przez turystów. Dodatkowo pozyskano informacje dotyczące sylwetki turysty odwiedzającego PPN, predysponującej m.in. wielkość i zakres usług turystycznych realizowanych w otoczeniu Parku.

Wyniki badań wielkości i struktury ruchu turystycznego prowadzonych w polskich parkach narodowych (Czarnecki 2009, Prędki 2006, Wieniawska-Raj 2007) bazują głównie na monitoringu ruchu turystycznego na wybranych szlakach lub w punktach wejściowych do stref chronionych, natomiast bardzo rzadko dotyczą całego obszaru objętego ochroną. W Pienińskim Parku Narodowym monitoring ruchu turystycznego prowadzony był przez A. Celichowskiego (1976) oraz J. Fischbacha (1985). Pozostałe opracowania dotyczące wielkości ruchu turystycznego w PPN odnoszą się do szacowanej liczby turystów na podstawie sprzedanych biletów na platformach widokowych (Okrąglica i Sokolica), udostępnionych przez Dyrekcję Pienińskiego Parku Narodowego.

Odrębna grupa prac dotyczy wpływu turystów na środowisko geograficzne w różnych regionach Polski i jest oparta na wynikach badań nad presją m.in. na rzeźbę terenu (Czochański 2000, Fidelus 2008, Gorczyca 2000, Kasprzak 2005, Krusiec 1996, Łajczak 1996, Szydarowski 2000, Wałdykowski 2006), glebę (Czapski i Mizgajska 1996, Degórski 
2002, Łajczak 1996, Prędki 2002) i szatę roślinną (Guzikowa 1982, Skawiński 1993, Skawiński i Krzan 2002).

\section{MONITORING RUCHU TURYSTYCZNEGO W PPN}

Monitoringiem natężenia ruchu turystycznego objęto łącznie 25612 turystów w 2007, 2008 i 2009 roku, w trakcie 19 dni pomiarów, bazując na liczeniu i określaniu kierunków przemieszczania się turystów w 13 punktach na poszczególnych odcinkach szlaków w obrębie PPN (tab. 1) przez siedem godzin na dobę w sposób ciagły w godzinach 9:00-16:00. Pomiary przeprowadzono w lipcu w terminach: 16-29.07.2007 roku (w tym osiem dni pomiaru natężenia ruchu turystycznego), 14-28.07.2008 roku (sześć dni pomiaru natężenia) oraz 13-27.07.2009 roku (pięć dni pomiaru natężenia), czyli okresach wakacyjnych, gdy zainteresowanie turystów PPN potencjalnie wzrasta.

Tab. 1. Rozmieszczenie punktów pomiaru natężenia ruchu turystycznego w PPN

\begin{tabular}{|l|l|}
\hline 1 & $\begin{array}{l}\text { Punkt na odcinku Szczawnica-Sokolica, pomiędzy wejściem do Parku od strony wschodniej } \\
\text { w Szczawnicy a Sokolicą (747 m n.p.m.) }\end{array}$ \\
\hline 2 & $\begin{array}{l}\text { Przełęcz Sosnów, na wysokości } 650 \text { m n.p.m., gdzie krzyżują się szlaki niebieski w kierunku } \\
\text { Sokolicy, niebieski w kierunku Czertezika i zielony w kierunku Krościenka }\end{array}$ \\
\hline 3 & $\begin{array}{l}\text { Punkt na odcinku Walusiówka-Toporzyska, położony na zielonym szlaku pomiędzy Polaną } \\
\text { Walusiówka a wejściem do Parku od strony północnej z Krościenka }\end{array}$ \\
\hline 4 & $\begin{array}{l}\text { Punkt na odcinku Toporzyska-Wymiarki, położny przy żółtym szlaku biegnącym przez punkt } \\
\text { graniczny PPN - Toporzyska w stronę Polany Wymiarki }\end{array}$ \\
\hline 5 & $\begin{array}{l}\text { Punkt na odcinku Walusiówka-Wymiarki, położony na niebieskim szlaku łączącym Polanę } \\
\text { Walusiówka z Polaną Wymiarki }\end{array}$ \\
\hline 6 & $\begin{array}{l}\text { Punkt na odcinku Wymiarki-Limierczyki, położony przy żółtym i niebieskim szlaku } \\
\text { pomiędzy Polaną Wymiarki a Polaną Limierczyki }\end{array}$ \\
\hline 7 & $\begin{array}{l}\text { Punkt na odcinku Limierczyki-Kosarzyska położony przy niebieskim szlaku biegnącym } \\
\text { z Polany Limierczyki przez Zamkową Górę na Polanę Kosarzyska }\end{array}$ \\
\hline 8 & $\begin{array}{l}\text { Punkt na odcinku Limierczyki-Przełęcz Szopka, położony na szlaku żółtym, } \\
\text { który łączy Limierczyki z Przełęczą Szopka (779 m n.p.m.) }\end{array}$ \\
\hline 9 & $\begin{array}{l}\text { Punkt na odcinku Przełęcz Szopka-Trzy Korony, położony przy niebieskim szlaku biegnącym } \\
\text { z Przełęczy Szopka na Trzy Korony (982 m n.p.m.) }\end{array}$ \\
\hline 10 & $\begin{array}{l}\text { Przełęcz Trzy Kopce, na wysokości 795 m n.p.m., gdzie krzyżują się szlaki: niebieski w kie- } \\
\text { runku Czorsztyna, niebieski w kierunku Przełęczy Szopka i czerwony w kierunku Sromowiec } \\
\text { Wyżnych }\end{array}$ \\
\hline 11 & $\begin{array}{l}\text { Punkt na odcinku Podłaźce-Przełęcz Szopka, położony na żółtym szlaku pomiędzy } \\
\text { wejściem do Parku ze Sromowiec Niżnych a Przełęczą Szopka }\end{array}$ \\
\hline 12 & $\begin{array}{l}\text { Punkt na odcinku Podłaźce-Kosarzyska, położony na zielonym szlaku pomiędzy wejściem } \\
\text { do Parku od strony południowej ze Sromowiec Wyżnych a Polaną Kosarzyska }\end{array}$ \\
\hline 13 & $\begin{array}{l}\text { Punkt na odcinku Kosarzyska-Trzy Korony, położony na niebieskim szlaku biegnącym } \\
\text { z Polany Kosarzyska na Trzy Korony }\end{array}$ \\
\hline
\end{tabular}


Kwestionariusz jaki obowiązywał przy monitoringu, zawierał kierunek przybycia i odejścia turystów, których konkretną liczbę odnotowywano w odstępach piętnastominutowych. Dodatkowo w kwestionariuszu wyróżniano duże grupy (powyżej 10 osób) oraz grupy z przewodnikiem.

Należy wyraźnie zaznaczyć, iż w przypadku Pienińskiego Parku Narodowego nie jest możliwe szacowanie natężenia ruchu turystycznego na podstawie biletów wstępu. Wstęp na teren Parku jest bezpłatny, na mocy Ustawy o ochronie przyrody z dnia 16 kwietnia 2004 r. (Dz. U. Nr 92, poz. 880) i Rozporządzenia Ministra Środowiska z dnia 18 maja 2005 r., w sprawie parków narodowych lub niektórych ich obszarów, gdzie za wstęp pobiera się opłaty (Dz. U. Nr 91, poz. 765). Opłaty pobierane są jedynie za udostępnienie wybranych miejsc, jak galerie widokowe na szczytach Trzech Koron i Sokolicy.

Odrębną grupę prac stanowiły badania ankietowe zmierzające do określenia profilu turysty odwiedzającego PPN, którymi objęto próbę liczącą 752 respondentów. Liczba przeprowadzonych ankiet, wyznaczona na podstawie danych z monitoringu, była proporcjonalna do wielkości natężenia ruchu turystycznego w danym punkcie.

\section{NATĘŻENIE RUCHU TURYSTYCZNEGO W PPN}

W badanych trzech przekrojach czasowych największa liczba turystów decydowała się na wejście na Trzy Korony z Przełęczy Szopka. Przykładowo w 2009 roku było to średnio 1238 osób dziennie $(2007=1200$ os./dobę, $2008=948$ os./dobę $)$. Ten odcinek szlaku jest najbardziej eksploatowanym w PPN. Często uczęszczanymi traktami turystycznymi były:

- odcinek żółtego szlaku między punktem Wymiarki i Limierczyki, który pokonało w 2009 roku średnio 1071 turystów dziennie $(2007=1000$ os./dobę, $2008=720$ os./dobę),

- odcinek Sokolica-Przełęcz Sosnów, na którym wielkość ruchu turystycznego kształtowała się w 2009 roku w granicach 700 osób na dobę $(2007=500$ os./dobę, $2008=350$ os./dobę),

- odcinek Szczawnica-Sokolica, pokonany średnio w 2009 roku przez 390 osób dziennie $(2007=270$ os./dobę, $2008=240$ os./dobę $)$.

Najmniej popularne wśród turystów odcinki szlaków w Pienińskim Parku Narodowym przebiegały przez punkt Przełęcz Trzy Kopce, a także na odcinku zielonego szlaku z Polany Walusiówka do punktu granicznego PPN - Toporzyska.

Wielkości opisujące natężenie ruchu turystycznego, w tym wskaźniki liczby turystów przypadające na dobę i kilometr kwadratowy PPN zestawiono w tabeli 2.

Tab. 2. Natężenie ruchu turystycznego w PPN w lipcu 2007, 2008 i 2009 roku

\begin{tabular}{|l|c|c|c|}
\hline & Liczba turystów w PPN & Liczba turystów/dobę & Liczba turystów na km² \\
\hline $2007(8 \mathrm{dni})$ & 11264 & 1408 & 60 \\
\hline $2008(6 \mathrm{dni})$ & 6961 & 1160 & 49 \\
\hline $2009(5 \mathrm{dni})$ & 7387 & 1477 & 63 \\
\hline
\end{tabular}


Wyraźnie należy zaznaczyć, iż w 2008 roku większość dni, na które przypadały badania, charakteryzowało się warunkami atmosferycznymi niesprzyjającymi pieszym wędrówkom (intensywne opady deszczu). Zarówno w 2007, jak i 2008 roku liczba turystów odwiedzających Park w okresie weekendu była większa niż w poszczególne dni powszednie (o około 10-15\%), nie znalazło to jednak potwierdzenia w badaniach prowadzonych w 2009 roku.

Za najpopularniejsze należy uznać wejście do Parku z Krościenka, na które zdecydowało się średnio 601 osób dziennie (2009). Stanowi to aż 41\% ogólnej liczby wejść do PPN, w odsetku tym zawierają się przede wszystkim turyści wchodzący do Parku żółtym i zielonym szlakiem przez punkt Toporzyska, ale także idący zielonym szlakiem wzdłuż Dunajca na Przełęcz Sosnów. Docelowo ta grupa turystów zmierza głównie na Trzy Korony i Sokolicę.

$\mathrm{Na}$ drugim miejscu pod względem liczby wstąpień do Parku plasują się Sromowce Niżne ('średnio 454 os./dobę w 2009 roku) z 31\% ogółu wejść. Sromowce, z których wychodzą szlaki na Trzy Korony przez Polanę Kosarzyska lub Wąwóz Sobczański, swoją wysoką pozycję w generowaniu liczby turystów wchodzących na teren Parku zawdzięczają bliskości głównej atrakcji parku - punktu widokowego na Okraglicy oraz obecności przejścia granicznego Sromowce Niżne-Czerwony Klasztor.

Interesującym jest fakt, iż dopiero na trzecim miejscu pod względem liczby wejść na teren PPN znajduje się największy ośrodek turystyczny regionu - Szczawnica, z której wchodzi na teren PPN zdecydowanie mniej osób niż z Krościenka - średnio 309 os./dobę, czyli 21\% ogółu wejść (2009). Ze Szczawnicy na teren Parku wejść można niebieskim szlakiem prowadzącym bezpośrednio na Sokolice, po pokonaniu naturalnej bariery rzecznej tratwą flisacką. Fakt ten istotnie wpływa na liczbę turystów zainteresowanych wejściem do PPN. W opinii respondentów istotną rolę odgrywa także odległość, która dzieli Szczawnicę od najbardziej popularnych w Pieninach Trzech Koron. Generalnie należy przyjąć, iż to właśnie Trzy Korony, na które prowadzą o wiele krótsze szlaki, m.in. z Krościenka i Sromowców Niżnych, a nie Sokolica, stanowią dla większości turystów główny punkt docelowy wycieczek w PPN. Pozostałe ośrodki, z najsłabszą infrastrukturą noclegową i znacznymi odległościami od głównych atrakcji Parku - Czorsztyn i Sromowce Wyżne, nie odgrywają istotnej roli w generowaniu liczby turystów wchodzących na jego teren.

\section{Przybliżona sylwetka tURysty OdWiedzajĄCEGo PPN}

W strukturze wieku turystów odwiedzających PPN nie zaznaczyła się wyraźna dominacja którejkolwiek grupy wiekowej, a średni wiek turystów to 32 lata (lipiec 2009). Najstarsza osoba jaką zankietowano miała 70 lat, natomiast najmłodsza - o której wiek zapytano jej rodziców - 3 lata. Turyści legitymujący się wykształceniem wyższym stanowili w lipcu 2009 roku prawie połowę respondentów, a pozostali reprezentowali: średnie (28\%), zasadnicze zawodowe $(19 \%)$, pomaturalne $(5 \%)$ i podstawowe $(1 \%)$ wykształcenie. Tak wysoki odsetek ankietowanych turystów z wyższym wykształceniem znalazł potwierdzenie w danych z 2007 i 2008 roku.

Wyniki badań z lat 2007, 2008 i 2009 wskazały, że turyści odwiedzający PPN pochodzą głównie z województw: małopolskiego, śląskiego, mazowieckiego i łódzkiego, z których to rejonów respondenci stanowili łącznie ponad 50\% całej zbadanej populacji. Analiza pytań ankietowych dotyczących częstości przyjazdów w Pieniny wskazuje, iż w latach 2007-2009 
respondenci odwiedzający Pieniny po raz piąty lub częściej przeważali wśród mieszkańców województwa małopolskiego. Stanowili oni większość także we wszystkich badanych okresach wśród turystów przyjeżdżających w Pieniny tylko na jeden dzień. Respondenci ze wskazanych wyżej województw: śląskiego, mazowieckiego i łódzkiego, spędzali w Pieninach docelowo większą liczbę dni (w grupie tej deklaracje jednodniowego pobytu dotyczyły osób przebywających na dłużej w okolicznych regionach turystycznych - głównie w Tatrach, Pogórzu Spisko-Gubałowskim i Beskidach).

W 2009 roku, podobnie jak w 2007 oraz 2008, najliczniejsza grupa turystów (ponad 60\%) wybrała zakwaterowanie w Krościenku oraz Szczawnicy, przy minimalnej przewadze pierwszej miejscowości, pomimo iż to Szczawnica dysponuje zdecydowanie liczniejszą bazą noclegową. Należy wnioskować, że w Szczawnicy przebywają głównie wczasowicze, którzy mniej chętnie decydują się na piesze wędrówki w obrębie PPN. Pośrednio samo usytuowanie Krościenka w niedalekiej odległości od dwóch głównych atrakcji Parku - punktów widokowych na Okraglicy i Sokolicy - sprzyja wyborowi jego bazy noclegowej. W wynikach ankiet zauważalny jest stopniowy wzrost popularności bazy noclegowej w pozostałych (obok Krościenka i Szczawnicy) miejscowościach leżących blisko granic Parku. Zdecydowana większość turystów korzystających z noclegu w rejonie PPN w lipcu 2009 roku odnotowała pobyt minimum trzydniowy. Turyści, którzy zdecydowali się na pobyt powyżej siedmiu dni, najczęściej wybierali Szczawnicę. Wykazano, że ponad połowa turystów odwiedzających PPN w lipcu 2009 roku wybierała kwatery prywatne jako miejsce noclegu, co piąty turysta decydował się na zakwaterowanie w pensjonatach. W dniach, w których prowadzono inwentaryzację bazy noclegowej, odnotowano różny stopień obłożenia miejsc noclegowych w poszczególnych miejscowościach, wynikający z różnic cen wynajmu oraz standardu wyposażenia i oferowanych usług. Najwięcej miejsc wykorzystanych było w uzdrowiskowej Szczawnicy (84\%), przy czym maksymalnym obsadzeniem miejsc przez turystów cechowały się głównie sanatoria i całkowicie zajęte pola namiotowe. Znaczny udział miejsc zajętych (76\%) odnotowano także w Czorsztynie.

\section{Literatura}

Celichowski A., 1976, „Plan ogólny zagospodarowania przestrzennego Pienińskiego Parku Narodowego. I etap - Prace przygotowawcze i zebranie materiałów”, maszynopis, Dyrekcja Pienińskiego Parku Narodowego.

Czapski Z., Mizgajska H., 1996, Biologiczne skażenie szlaków turystycznych Tatrzańskiego Parku Narodowego, [w:] Z. Krzan (red.), Przyroda Tatrzańskiego Parku Narodowego a Człowiek, 3. Wplyw człowieka, Kraków-Zakopane, s. 46-47.

Czarnecki K., 2009, Atrakcyjność turystyczna i ruch turystyczny w parkach narodowych województwa podlaskiego, Zeszyty Naukowe SGGW, 73, Ekonomika i organizacja gospodarki żywnościowej, Warszawa, s. 165-175.

Czochański J., 2000, Wplyw użytkowania turystycznego na rozwój procesów i form erozyjno-denudacyjnych $w$ otoczeniu szlaków, [w:] J. Czochański, D. Borowiak (red.), Z badań geograficznych w Tatrach Polskich, Wyd. Uniwersytetu Gdańskiego, Gdańsk, s. 331-344.

Degórski M., 2002, Ocena wpływu antropopresji na wybrane właściwości pokrywy glebowej piętra subalpejskiego $i$ alpejskiego $w$ rejonie Kasprowego Wierchu, [w:] W. Borowiec, A. Kotarba, A. Kownacki, Z. Krzan, Z. Mirek (red.), Przemiany środowiska przyrodniczego Tatr, Instytut Botaniki PAN, Kraków-Zakopane, s. 395-402. 
Fidelus J., 2008, Rola ruchu turystycznego w przeksztatcaniu ścieżek $i$ dróg turystycznych na obszarze $T P N$, Prace Geograficzne, 120, Kraków, s. 20-29.

Fischbach J., 1985, „Wielkość i struktura ruchu turystycznego w Pienińskim Parku Narodowym”, maszynopis, Dyrekcja Pienińskiego Parku Narodowego.

Gorczyca E., 2000, Wpływ ruchu turystycznego na przekształcenie rzeźby wysokogórskiej na przykładzie Masywu Czerwonych Wierchów i Regli Zakopiańskich (Tatry Zachodnie), Prace Geograficzne, IGiPZ, 105, Kraków, s. 369-389.

Kasprzak M., 2005, Tempo degradacji powierzchni dróg i ścieżek turystycznych w Karkonoszach Wschodnich, Opera Corcontica, 41, s. 17-30.

Guzikowa M., 1982, Wpływ pieszego ruchu turystycznego na szate roślinna Pienińskiego Parku Narodowego (wybrane zagadnienia, ze szczególnym uwzględnieniem skutków wydeptania), Studia Naturae, Seria A, PAN, 22, s. 227-241.

Krusiec M., 1996, Wpływ ruchu turystycznego na przekształcenie rzeźby Tatr Zachodnich na przykładzie Doliny Chochołowskiej, Czasopismo Geograficzne, 67, 3-4, s. 303-320.

Łajczak A., 1996, Wplyw narciarstwa i turystyki pieszej na erozje gleby w obszarze podszczytowym Pilska, [w:] A. Lajczak, S. Michalik, Z. Witkowski (red.), Wplyw narciarstwa i turystyki pieszej na przyrodę masywu Pilska, Studia Naturae, Seria A, PAN, 41, s. 131-159.

Prędki R., 2002, Wptyw ruchu turystycznego na teksturę oraz wtaściwości wodne gleb w obrębie szlaków pieszych Bieszczadzkiego Parku Narodowego, [w:] J. Partyka (red.), Użytkowanie parków narodowych. Ruch turystyczny - zagospodarowanie - konflikty - zagrożenia, Wyd. Ojcowski Park Narodowy, Ojców, s. 763-770.

Prędki R., 2006, Bieszczadzki Park Narodowy w świetle badań ankietowych turystów na szlakach pieszych w latach 2004-2005, Rocznik Bieszczadzki, 14, s. 285-297.

Skawiński P., 1993, Oddziaływanie człowieka na przyrodę kopuły Kasprowego Wierchu oraz Doliny Goryczkowej w Tatrach, [w:] W. Cichocki (red.), Ochrona Tatr w obliczu zagrożeń, Wyd. Muzeum Tatrzańskiego, Zakopane, s. 197-226.

Skawiński P., Krzan Z., 2002, Restytucja szaty roślinnej kopuły Kasprowego Wierchu w latach 1993-2001, [w:] W. Borowiec, A. Kotarba, A. Kownacki, Z. Krzan, Z. Mirek (red.), Przemiany środowiska przyrodniczego Tatr, Instytut Botaniki PAN, Kraków-Zakopane, s. 407-411.

Szydarowski W., 2000, Rozwój form erozyjnych w otoczeniu szlaków turystycznych Tatrzańskiego Parku Narodowego, [w:] J. Czochański, D. Borowiak (red.), Z badań geograficznych w Tatrach Polskich, Wyd. Uniwersytetu Gdańskiego, Gdańsk, s. 315-328.

Wałdykowski P., 2006, Wplyw dróg górskich na dynamikę procesów morfogenetycznych $w$ rejonie Turbacza, Ochrona Beskidów Zachodnich, 1, s. 67-79.

Wieniawska-Raj B., 2007, Dynamika ruchu turystycznego w Karkonoskim Parku Narodowym, [w:] J. Štursa, R. Knapik (red.), Geoekologické problémy Krkonoš, Sborn. Mez. Věd. Konf., Svoboda n. Úpou, Opera Corcontica, 44/2, s. 593-602.

\section{Tourist traffic intensity in the Pieniny National Park}

The paper presents the results of tourist traffic monitoring carried out in years 2007-2009 by SKNG UP in the Pieniny National Park. The study included a survey of 25,612 visitors and allowed to estimate the intensity of tourist traffic in the Pieniny National Park and its spatial variability, as well as to determine the main routes and the most popular marked paths within the Park. The questionnaires allowed to determine the types and preferences of the visitors to the Pieniny National Park.

During 19 days of monitoring, carried out repeatedly in 2007, 2008 and 2009, surveyors standing at the selected measure points counted and surveyed the visitors for 7 hours per day $(9 \mathrm{am}-4 \mathrm{pm})$. In July 2007, the intensity of tourist traffic in the PPN reached 1,408 people per day (60 visitors $/ 1 \mathrm{~km}^{2}$ of PPN/day), 1,160 people per day (49 visitors $/ 1 \mathrm{~km}^{2}$ of PPN/day) in July 2008, and 1,477 people/day 
(63 visitors $/ 1 \mathrm{~km}^{2}$ of PPN/day) in July 2009. The most popular routes in the PPN included: the section between Przełęcz Szopka - Trzy Korony with 1,200, 948 and 1,238 people per day in the years 2007, 2008 and 2009, respectively, the section Wymiarki - Limierczyki with 1,000, 720 and 1,071 visitors per day (2007-2009), and the section Sokolica - Przełęcz Sosnów: 500, 350, and 700 visitors per day (2007-2009). The most popular place to visit in the Pieniny National Park was Krościenko, receiving twice as many visitors as the largest tourist resort in this region - Szczawnica. Their average age was about 30 years old and approximately half of the respondents were people who hold university degree. The majority of the tourists came from Lesser Poland, Silesia, Masovian and Lodz voivodeships (the total number of over 50\%). Those who were visiting the Pieniny for the fifth time or more prevailed among Lesser Poland inhabitants. Furthermore, they were also the majority of the one-day visitors to these mountains. Krościenko and Szczawnica turned out to be the most popular accommodation places chosen by $61 \%$ of the tourists. The vast majority of guests reported a three-day minimum stay and most of them gave preference to private accommodation.

dr Witold Warcholik

Uniwersytet Pedagogiczny w Krakowie

Instytut Geografii

Zakład Turystyki i Badań Regionalnych

e-mail: witek.maciej@gmail.com

mgr Marcin Semczuk

Uniwersytet Pedagogiczny w Krakowie

Instytut Geografii

Zakład Przedsiębiorczości i Gospodarki Przestrzennej

e-mail: semczuk@interia.eu 